\title{
CDKN2A Gene Mutation Negative
}

National Cancer Institute

\section{Source}

National Cancer Institute. CDKN2A Gene Mutation Negative. NCI Thesaurus. Code C148083.

A genetic finding indicating that CDKN2A gene mutations have not been detected in a sample. 